REFLEKSI HUKUM

Jurnal Ilmu Hukum
p-ISSN 2541-4984 | e-ISSN 2541-5417

Volume 4 Nomor 2, April 2020, Halaman 175-194

DOI: https://doi.org/10.24246/jrh.2020.v4.i2.p175-194

Open access at: http://ejournal.uksw.edu/refleksihukum

Penerbit: Fakultas Hukum Universitas Kristen Satya Wacana

\title{
PENERAPAN PRINSIP KEBEBASAN BERKONTRAK DALAM KONTRAK STANDAR PENGADAAN BARANG DAN JASA PEMERINTAH DI INDONESIA
}

\author{
Muskibah dan Lili Naili Hidayah \\ Fakultas Hukum Universitas Jambi \\ Korespondensi: muskibah@yahoo.co.id
}

Naskah dikirim: 31 Oktober 2019|Direvisi: 31 Januari 2020|Disetujui: 27 April 2020

\begin{abstract}
Abstrak
Kebebasan berkontrak bukanlah kebebasan tanpa batas. Kontrak standar pengadaan barang dan jasa pemerintah merupakan salah satu pembatas kebebasan berkontrak. Pembentukan dan pengaturan hak dan kewajiban yang termuat dalam kontrak pengadaan barang dan jasa, didasarkan pada peraturan standar yang termuat dalam Standar Dokumen Pengadaan/Standar Dokumen Pengadaan Secara Elektronik. Penelitian ini bertujuan untuk menganalisis keberlakuan prinsip kebebasan berkontrak dalam kontrak standar, serta bentuk kebebasan berkontrak dalam kontrak standar pengadaan barang dan jasa pemerintah. Melalui penelitian yuridis normatif, penelitian ini menemukan kontrak standar bertentangan dengan prinsip kebebasan berkontrak. Namun demikian, ditemukan bentuk kebebasan berkontrak dalam kontrak pengadaan barang dan jasa pemerintah yaitu pada tahapan pra kontraktual. Pada tahapan kontraktual dan tahapan post kontraktual, kebebasan berkontrak hanya merupakan pelaksanaan dari ketentuan undang-undang. Untuk itu, rekomendasi dari penelitian ini adalah perlu dilakukan perubahan terhadap ketentuan mengenai hak dan kewajiban para pihak baik pada tahap pra kontraktual, kontraktual, maupun post kontraktual pada kontrak pengadaan barang dan jasa.
\end{abstract}

Kata-kata Kunci: Kebebasan Berkontrak; Kontrak Pengadaan Barang dan Jasa.

\begin{abstract}
Freedom of contract is not freedom without limits. The standard form of contract for the procurement of goods and services of the government is one of the limitations on the freedom of contract. The formulation and arrangement of rights and obligations in the contract for the procurement of goods and services are based on the standard regulation as embedded in the Standard Document Procurement/ Electronic Standard Document Procurement. This research analyzes the validity of the freedom of contract principle in the standard contract and the standard contract for the procurement of government goods and services as well. This legal research concluded that the standard contract contradicts the freedom of contract principle. Nevertheless, the freedom of contract can be found at the pre-contractual stage of the standard contract for the procurement of government goods and services. Therefore, this research recommends that it is necessary to change the provision on the rights and obligations of the parties at the pre-contractual stage, the contractual stage, and the postcontractual stage as well.
\end{abstract}

Keywords: Freedom of Contract; Procurement of Goods and Services Contract. 


\section{PENDAHULUAN}

Pengadaan barang dan jasa untuk kepentingan pemerintah merupakan salah satu alat untuk menggerakkan roda perekonomian, dalam rangka meningkatkan perekonomian nasional guna mensejahterahkan kehidupan rakyat Indonesia, karena pengadaan barang dan jasa terutama di sektor publik terkait erat dengan penggunaan anggaran negara. ${ }^{1}$ Pengaturan pengadaan barang/jasa pemerintah terdapat dalam Peraturan Presiden Nomor 16 Tahun 2018 tentang Pengadaan Barang/Jasa Pemerintah (Perpres Pengadaan Barang/Jasa Pemerintah). Hubungan kerja antara pemerintah dengan penyedia barang dan jasa dituangkan dalam suatu kontrak. Kontrak yang di dalamnya pemerintah terlibat sebagai salah satu pihak, dapat berupa kontrak pengadaan dan kontrak non pengadaan. Kontrak pengadaan dimaksudkan untuk pengadaan barang dan jasa pemerintah, sedangkan kontrak non pengadaan adalah untuk pelayanan publik. Dari sisi anggaran, kontrak pengadaan merupakan kontrak yang menimbulkan beban pembayaran baik dari Anggaran Pendapatan dan Belanja Nasional (APBN), dari Anggaran Pendapatan dan Belanja Daerah (APBD), ataupun dari pinjaman luar negeri, sedangkan kontrak non pengadaan pada umumnya kontrak yang menghasilkan pemasukan. ${ }^{2}$

Kontrak pengadaan barang dan jasa pemerintah adalah perjanjian tertulis antara Pengguna Anggaran (PA)/Kuasa Pengguna Anggaran (KPA) dengan penyedia barang dan jasa. Terkait dengan kedudukan pemerintah sebagai salah satu pihak dalam kontrak pengadaan barang dan jasa, mengakibatkan di satu sisi pemerintah terikat pada norma privat khususnya dalam hubungannya dengan kontrak, akan tetapi di sisi lain dalam kedudukan sebagai badan hukum publik, pemerintah terikat pada ketentuan yang terdapat dalam konstitusi dan undang-undang (UU).

Dalam konteks pembentukan kontrak pengadaan barang dan jasa pemerintah, dapat dikatakan bahwa perwujudan kehendak bebas para pihak dibatasi oleh peraturan perundang-undangan yang mengatur tentang pengadaan barang dan jasa, baik mengenai format, klausula dan ruang lingkupnya. Pembentukan dan pengaturan hak dan kewajiban yang termuat dalam kontrak pengadaan barang dan jasa, didasarkan pada peraturan standar yang termuat dalam Standar Dokumen Pengadaan (SDP)/Standar Dokumen Pengadaan Secara Elektronik (SDPSE) yang melekat pada aplikasi Sistem Pengadaan Secara Elektronik (SPSE). Penetapan peraturan standar tersebut tidak dilakukan atas dasar kesepakatan, kecuali kesepakatan atau persetujuan dalam bentuk penandatanganan. Kesepakatan yang demikian dapat dikatakan tidak diberikan secara bebas karena ketergantungan secara ekonomis pihak penyedia kepada pemerintah sebagai pihak pengguna, menyebabkan kebebasan bagi pihak penyedia hanya berupa pilihan menerima atau menolak

1 Apri Listiyanto, 'Pembaharuan Regulasi Pengadaan Barang dan Jasa Pemerintah' (2012) 1 (1) RechtsVinding: Media Pembinaan Hukum Nasional 113, 114.

2 Yohanes Sogar Simamora, Hukum Kontrak Pengadaan Barang dan Jasa Pemerintah di Indonesia (ed. ke-2, Kantor Hukum WINS \& Partners 2005) 47. 
peraturan-peraturan standar yang telah ditetapkan.

Pasal 1338 Kitab UndangUndang Hukum Perdata (KUH Perdata) menyebutkan, bahwa semua perjanjian yang dibuat secara sah mengikat para pihak sebagai UU. Pasal 1338 KUH Perdata tersebut pada dasarnya memuat prinsip kebebasan berkontrak, yakni setiap orang bebas untuk mengadakan atau tidak mengadakan kontrak, bebas untuk mengadakan kontrak dengan siapa yang dikehendaki, bebas untuk menentukan isi kontrak, bebas pula untuk menentukan bentuk kontrak, dan bebas menentukan ketentuanketentuan hukum yang berlaku dalam kontrak.

Di Indonesia penerapan prinsip kebebasan berkontrak tidak bersifat mutlak, ada pembatasan-pembatasan tertentu yang diatur dalam $\mathrm{KUH}$ Perdata maupun peraturan perundang-undangan lainnya. Pembatasan kebebasan berkontrak yang diatur dalam KUH Perdata diantaranya adalah tidak boleh adanya cacat dalam kesepakatan yaitu adanya paksaan, kekhilafan, dan penipuan. Ajaran penyalahgunaan keadaan (misbruik van omstandigheden) dapat digunakan dalam kategori cacat dalam menentukan kehendaknya untuk memberikan persetujuan. ${ }^{3}$ Kebutuhan konstruksi penyalahgunaan keadaan merupakan atau dianggap sebagai faktor yang membatasi atau yang mengganggu adanya kehendak yang bebas untuk menentukan persetujuan antara kedua belah pihak. ${ }^{4}$ Salah satu keadaan yang dapat disalahgunakan adalah karena ketergantungan secara ekonomi. Penyalahgunaan ketergantungan secara ekonomi dapat dilihat dari syarat-syarat yang diperjanjikan tidak masuk akal atau tidak patut atau bertentangan dengan perikemanusiaan, memberatkan, dimana nilai dan hasil dari perjanjian tidak seimbang jika dibandingkan dengan prestasi timbal balik dari para pihak. ${ }^{5}$

Dalam prakteknya pemberlakuan peraturan standar dilakukan dengan berbagai cara: dengan jalan penandatanganan, dengan pemberitahuan, dengan jalan penunjukan, dengan jalan diumumkan. ${ }^{6}$ Pemberlakuan peraturan standar dalam kontrak pengadaan barang dan jasa adalah dengan jalan penandatanganan, dimana peraturan standar tersebut dicantumkan dalam syaratsyarat umum dan syarat-syarat khusus kontrak yang merupakan satu kesatuan dengan dokumen kontrak pengadaan barang dan jasa lainnya. Penandatanganan kontrak mengakibatkan syarat-syarat umum dan syarat-syarat khusus kontrak tersebut mempunyai kekuatan mengikat.

Ridwan Khairandy berpendapat bahwa tahapan kontrak terdiri atas: Pertama, tahap penyusunan perjanjian/pra kontraktual (precontractuele fase). Kedua, tahap pelaksanaan isi perjanjian/kontraktual (contractuele fase). Ketiga, tahap paska kontraktual

\footnotetext{
3 Tami Rusli, 'Asas Kebebasan Berkontrak Sebagai Dasar Perkembangan Perjanjian di Indonesia' (2015) 10 (1) Pranata Hukum Jurnal Ilmu Hukum 24, 33.

4 Ni'matul Khoiriyah dan Lukman Santoso, 'Batasan Kebebasan Berkontrak dalam Kontrak Konvensional dan Kontrak Syariah' (2017) 5 (1) AHKAM 41, 48.

5 Muhammad Arifin, 'Penyalahgunaan Keadaan Sebagai Faktor Pembatas Kebebasan Berkontrak' (2011) 22 (2) Jurnal Ilmu Hukum 280, 285.

6 Sri Soedewi Maschoen Sofwan, Hukum Perdata: Hukum Perutangan (Seksi Hukum Perdata Fakultas Hukum Universitas Gadjah Mada 1980) 58.
} 
(post contractuele). ${ }^{7}$ Asas konsensualisme dan asas kebebasan berkontrak terletak pada periode pra kontraktual, sehingga lahir kontrak yang disepakati dengan adanya janji kemauan yang timbul bagi para pihak untuk saling berprestasi dan ada kemauan untuk saling mengikatkan diri. ${ }^{8}$ Kebebasan berkontrak dapat dimaknai sebagai kebebasan berkontrak yang positif dan negatif. Kebebasan berkontrak yang positif dimaknai sebagai kebebasan untuk membuat kontrak yang mengikat dan mencerminkan kehendak bebas para pihak. Kebebasan berkontrak dalam arti negatif bermakna bahwa para pihak bebas dari suatu kewajiban sepanjang kontrak tersebut tidak mengaturnya. ${ }^{9}$

Doktrin mendasar yang melekat pada kebebasan berkontrak adalah kontrak dilahirkan ex nibilo, yakni kontrak sebagai perwujudan kebebasan kehendak (free will) para pihak yang membuat kontrak. Bahkan pada tahun 1870 sebagai puncak penerapan prinsip kebebasan berkontrak, pemerintah maupun pengadilan sama sekali tidak dibenarkan intervensi terhadap kontrak para pihak, serta muncul doktrin caveat emptor atau the buyer beware yang artinya hukum mewajibkan pembeli untuk berhatihati dan harus berupaya menjaga diri mereka sendiri. ${ }^{10}$ Namun paradigma kebebasan berkontrak bergeser ke arah paradigma kepatutan. Walaupun kebebasan berkontrak masih menjadi asas penting dalam hukum perjanjian baik dalam civil law maupun common law, tetapi ia tidak lagi muncul seperti kebebasan berkontrak tanpa batas. Negara telah melakukan sejumlah pembatasan kebebasan berkontrak melalui peraturan perundangundangan dan putusan pengadilan. ${ }^{11}$

Berdasarkan pemahaman dari makna kebebasan berkontrak dalam kaitannya dengan kontrak pengadaan barang dan jasa yang dibentuk berdasarkan SDP, tentunya kontrak pengadaan barang dan jasa tersebut bertentangan dengan asas kebebasan berkontrak. Kontrak sebagai hubungan hukum antara dua pihak atau lebih didasarkan pada kata sepakat untuk menimbulkan suatu akibat hukum, sehingga kedua belah pihak sepakat untuk menentukan kaedah atau hak dan kewajiban yang mengikat para pihak untuk dijalankan. Kesepakatan menimbulkan akibat hukum yang adil dalam bentuk hak dan kewajiban sesuai dengan proporsionalnya.

Kewajiban yang dimaksud adalah kewajiban hukum, tidak termasuk di dalamnya kewajiban moral. Dalam KUH Perdata, yang dimaksud dengan kewajiban tersebut adalah kewajiban untuk berbuat sesuatu dan kewajiban untuk tidak berbuat sesuatu sebagaimana yang diatur dalam Pasal 1239 dan Pasal 1240 KUH Perdata. Oleh karena itu melalui penelitian ini, permasalahan yang akan diteliti: Pertama, bagaimana hubungan antara kebebasan berkontrak dengan perjanjian standar. Kedua, bagaimana implementasi bentuk-bentuk prinsip

7 Ridwan Khairandy, Itikad Baik dalam Kebebasan Berkontrak (Program Pascasarjana Fakultas Hukum Universitas Indonesia 2003) 90.

$8 \quad$ Ridwan Khairandy, Hukum Kontrak Indonesia dalam Perspektif Perbandingan (FH UII Press 2013) 37.

$9 \quad$ Ibid., 42.

10 Made Rawa Aryawan, 'Asas Kebebasan Berkontrak dalam Kaitannya dengan Kewenangan Hakim untuk Menilai Eksistensi Kontrak' (2003) 1 (1) Jurnal Ilmu Hukum 1.

11 Ridwan Khairandy, Itikad Baik dalam Kebebasan Berkontrak (n 7) 43. 
kebebasan berkontrak dalam kontrak standar pengadaan barang dan jasa pemerintah di Indonesia.

Tipe penelitian yang digunakan pada penelitian ini adalah yuridis normatif. Pendekatan yang digunakan adalah pendekatan perundangundangan dan pendekatan konseptual. Bahan hukum yang digunakan untuk menganalisis permasalahan hukum yang diteliti terdiri dari bahan hukum primer, bahan hukum sekunder, dan bahan hukum tersier. Analisis bahan hukum dalam penelitian ini dilakukan dengan menggunakan metode interpretasi yaitu interpretasi sistematis. Interpretasi sistematis adalah interpretasi dengan melihat kepada hubungan di antara aturan dalam suatu UU yang saling bergantung. Metode interpretasi dilakukan terhadap semua bahan hukum yang telah diolah selanjutnya diuraikan secara terperinci dan komprehen-sif dalam bentuk uraian yang sistematis. Penarikan kesimpulan dari hasil analisis dilakukan dengan menggunakan metode deduktif yaitu menyimpulkan hasil penelitian dari hal-hal yang umum kepada hal-hal yang khusus.

\section{PEMBAHASAN}

\section{Kebebasan Berkontrak dan Kontrak Standar}

Perjanjian atau kontrak melahirkan hubungan hukum bagi para pihak yang mengadakan perjanjian. Kebebasan berkontrak merupakan salah satu asas penting dalam hukum perjanjian. Asas identik dengan principle dalam bahasa Inggris yang secara etimologi memiliki tiga arti: 1) dasar (sesuatu yang menjadi tumpuan berpikir atau berpendapat; 2) dasar cita-cita; 3) hukum dasar. ${ }^{12}$ Asas atau prinsip adalah sesuatu yang dapat dijadikan alas, dasar, tumpuan, tempat untuk menyandarkan, untuk mengembalikan sesuatu hal, yang hendak dijelaskan. 13 Asas hukum merupakan jantungnya peraturan hukum, karena asas hukum adalah landasan yang paling luas bagi lahirnya suatu peraturan hukum. Selain itu, asas hukum juga merupakan ratio legis dari peraturan hukum. ${ }^{14}$ Menurut G.W. Paton, asas hukum merupakan alam pikiran yang melatarbelakangi pembentukan norma atau aturan hukum (a principle is the broad reason which lies at the base of rule of law). ${ }^{15}$

KUH Perdata memuat sejumlah asas hukum yang menjadi dasar bagi bangunan hukum perjanjian, yaitu: asas konsensualisme, asas kebebasan berkontrak, asas pacta sunt servanda, dan asas itikad baik. Asas konsensualisme merupakan momentum lahir dan mengikatnya perjanjian, yakni saat terjadinya kesepakatan antara para pihak mengenai hal-hal pokok yang diperjanjikan. Asas kekuatan mengikat merupakan konsekuensi dan implementasi dari asas konsensualisme. Asas kebebasan berkontrak berhubungan dengan isi dan syaratsyarat kontrak serta bentuk kontrak. Sementara asas itikad baik berkaitan tidak saja pada saat pelaksanaan

\footnotetext{
12 Kamus Besar Bahasa Indonesia Kamus versi online/daring (dalam jaringan), <https://kbbi.web.id/asas> diakses 20 Maret 2020.

Mahadi, Falsafah Hukum Suatu Pengantar (Citra Aditya Bakti1989) 119.

Satjipto Rahardjo, Ilmu Hukum (cet. ke-2, Citra Aditya Bakti 2000) 45.

G.W. Paton, A Textbook of Jurisprudence (3 $3^{\text {rd }}$ edn, ELBS And Oxford University Press 1971) 204.
} 
kontrak tetapi juga pada saat pembentukan kontrak atau pada saat perundingan untuk pembuatan kontrak.

Dalam kaitan mengenai asasasas hukum yang terdapat dalam hukum perjanjian, Yohanes Sogar Simamora mengemukakan, ada empat asas hukum yang terdapat dalam hukum kontrak, yaitu: asas kebebasan berkontrak, asas itikad baik, asas transparansi, dan asas proporsionalitas. ${ }^{16}$ Agus Yudha Hernoko mengemukakan asas proporsionalitas sebagai kajian utama yang dihubungkan dengan asas-asas pokok hukum kontrak, yaitu kebebasan berkontrak, asas konsensualisme, asas kekuatan mengikat dan asas itikad baik. ${ }^{17}$

Dari pendapat yang dikemukakan, asas kebebasan berkontrak merupakan asas yang penting dalam hukum perjanjian. Asas atau prinsip kebebasan berkontrak dapat ditemukan dalam Pasal 1338 ayat (1) KUH Perdata. Ketentuan pasal tersebut menegaskan bahwa semua kontrak yang dibuat secara sah berlaku sebagai UU bagi mereka yang membuatnya. Artinya wujud dari suatu kontrak haruslah dibangun atas dasar konsensus yang lahir dari kebebasan berkehendak dari para pihak yang hendak melakukan suatu kontrak. ${ }^{18}$ Penjabaran lebih lanjut asas atau prinsip kebebasan berkontrak meliputi ruang lingkup: 1) Kebebasan untuk membuat atau tidak membuat kontrak; 2) kebebasan memilih pihak dengan siapa ia ingin membuat kontrak; 3) kebebasan menentukan atau memilih kausa dari kontrak yang hendak dibuat; 4) kebebasan menentukan objek kontrak; 5) kebebasan menentukan bentuk kontrak; 6) Kebebasan untuk menerima atau menyimpangi ketentuan UU yang bersifat opsional (aanvullend, optional). ${ }^{19}$

Johannes Gunawan mengemukakan, secara historis sebenarnya asas kebebasan berkontrak meliputi lima macam kebebasan, yaitu: 1) Kebebasan para pihak menutup atau tidak menutup kontrak; 2) kebebasan menentukan dengan siapa para pihak akan menutup kontrak; 3) kebebasan para pihak menentukan bentuk kontrak; 4) kebebasan para pihak menentukan isi kontrak; 5) kebebasan para pihak menentukan cara penutupan kontrak. ${ }^{20}$

Pemberlakuan asas atau prinsip kebebasan berkontrak tidak selalu bermakna bebas mutlak, ada pembatasan-pembatasan yang diberikan oleh beberapa pasal dalam KUH Perdata. Asas konsensualisme yang terkandung dalam Pasal 1320 angka (1) KUH Perdata mengandung arti bahwa pembuatan suatu kontrak tidak sah apabila tidak ada kesepakatan dari salah satu pihak. Pasal 1320 angka (2) KUH Perdata dapat disimpulkan bahwa seseorang yang tidak cakap membuat kontrak tidak mempunyai

\footnotetext{
16 Yohanes Sogar Simamora, Hukum Kontrak-Kontrak Pengadaan Barang dan Jasa Pemerintah di Indonesia (n 2) 37.

17 Agus Yudha Hernoko, Hukum Perjanjian, Asas Proporsionalitas dalam Kontrak Komersial (Kencana Prenada Media Grup 2001) 89.

18 Muhammad Sjaiful, 'Karakteristik Asas Kebebasan Berkontrak dalam Perjanjian Berbasis Syariah' (2015) 15 (1) Jurnal Universitas Halu Oleo 69.

19 Sutan Remy Syahdeini, Kebebasan Berkontrak dan Perlindungan yang Seimbang Bagi Para Pihak dalam Perjanjian Kredit Bank di Indonesia (Institut Bankir Indonesia 1993) 47.

20 Johannes Gunawan, 'Reorientasi Hukum Kontrak di Indonesia' (2003) 22 (6) Jurnal Hukum Bisnis 47.
} 
kebebasan untuk membuat kontrak. Pasal 1320 angka (3) KUH Perdata menetapkan bahwa objek perjanjian haruslah dapat ditentukan, prestasi harus tertentu atau dapat ditentukan, jelas, ditentukan jenisnya, jumlahnya boleh tidak disebutkan tetapi dapat dihitung. Apabila prestasinya kabur, maka objek perjanjian dianggap tidak ada dan akibatnya perjanjian itu batal demi hukum. Pasal 1320 angka (4) juncto Pasal 1337 KUH Perdata yang menetapkan, bahwa para pihak tidak dibenarkan membuat kontrak atas dasar kausa yang tidak halal. Kausa yang tidak halal adalah yang dilarang atau bertentangan dengan UU, atau bertentangan dengan ketertiban umum dan kesusilaan. Kontrak yang dibuat atas dasar kausa yang tidak halal adalah tidak sah.

Selanjutnya, kebebasan berkontrak juga dibatasi oleh ketentuan Pasal $1321 \mathrm{KUH}$ Perdata mempertegas bahwa tidak ada kebebasan dalam kesepakatan yang diberikan atas dasar paksaan, kekhilafan, dan penipuan. Apabila hal tersebut terjadi maka akan mengakibatkan kontrak menjadi tidak sah. Begitu juga dengan asas itikad baik yang terdapat dalam Pasal 1338 ayat (3) KUH Perdata, yang membatasi kebebasan para pihak kecuali dilaksanakan dengan itikad baik.

Selain pembatasan yang terdapat dalam KUH Perdata, kebebasan berkontrak juga dipengaruhi oleh: 1) Makin berpengaruhnya ajaran itikad baik dimana itikad baik tidak hanya ada pada pelaksanaan kontrak, tetapi juga harus ada pada saat dibuatnya kontrak; 2) makin berkembangnya ajaran penyalahgunaan keadaan (misbruik van omstandigheden atau undue influence). ${ }^{21}$ Penyalahgunaan keadaan sebagai faktor yang membatasi kebebasan berkontrak, telah diterima Mahkamah Agung, antara lain dalam Putusan Nomor 2230K/Pdt/1985 dalam kasus PT. Adamson lawan PT BSN dan Putusan Nomor 2464K/Pdt/ 1986 dalam kasus Hotel Medan Utara lawan Bank Eksport Import Indonesia. Penerimaan ajaran penyalahgunaan keadaan ini oleh yurisprudensi merupakan upaya peradilan melindungi pihak yang lemah dari dominasi pihak yang kuat dalam memaksa pihak yang lemah untuk menandatangani kontrak, dimana kontrak tersebut sangat merugikan pihak yang lemah.

Masyarakat menginginkan kontrak tetap menjunjung asas atau prinsip umum hukum kontrak, yaitu asas kebebasan berkontrak yang meliputi kebebasan memilih hukum yang berlaku dan asas menentukan yuridiksi. Tetapi ada kecenderungan pelaku usaha untuk menutup kontrak dengan telah menyiapkan formatformat kontrak yang umumnya sudah tercetak untuk ditandatangani oleh mitra kontraknya. Hal itu telah menghilangkan atau paling tidak membatasi kebebasan berkontrak dari mitra kontraknya untuk secara seimbang dapat menegosiasikan isi kesepakatan yang dapat diterimanya. 22

Mariam Darus Badrulzaman mengemukakan bahwa pemberlakuan ruang lingkup atau bentuk-bentuk kebebasan berkontrak menjadi semakin sempit dilihat dari berbagai segi, yaitu: dari segi kepentingan umum, segi perjanjian baku (standard), dan

21 Ridwan Khairandy, Hukum Kontrak Indonesia dalam Perspektif Perbandingan (n 8) 2.

22 Ricardo Simanjuntak, 'Akibat dan Tindakan-Tindakan Hukum Terhadap Pencantuman Klausula Baku dalam Polis Asuransi yang Bertentangan Dengan Pasal 18 Undang-Undang Nomor 8 Tahun 1999 Tentang Perlindungan Konsumen' (2003) 22 (2) Jurnal Hukum Bisnis 56. 
segi perjanjian dengan pemerintah. ${ }^{23}$ Dalam hubungan dengan perjanjian standar, kebebasan berkontrak pada dasarnya memberikan ruang kebebasan pada para pihak. Akan tetapi mengenai isi dan bentuknya, biasanya sudah ditetapkan secara sepihak. Hal ini dikarenakan kedudukan para pihak dalam perjanjian standar tidak seimbang, salah satu pihak berada posisi tawar yang lebih kuat sebagai pihak yang menentukan, sementara pihak lain berada pada posisi tawar yang lemah yaitu sebagai pihak penerima.

Perjanjian standar sudah secara luas digunakan dalam setiap hubungan hukum dalam masyarakat. Latar belakang timbulnya karena keadaan sosial ekonomi, perusahaan besar dan perusahaan pemerintah mengadakan kerjasama dan untuk kepentingan kerjasama tersebut, ditentukan syarat-syarat secara sepihak. Akan tetapi penggunaan istilah perjanjian standar tersebut belum ada keseragaman baik dalam kepustakaan asing maupun dalam kepustakaan hukum di Indonesia. Dalam kepustakaan hukum di Indonesia dijumpai istilah kontrak standar, kontrak baku, perjanjian standar, perjanjian baku. Kontrak baku atau perjanjian standar didefinisikan secara berbeda-beda oleh para ahli, namun intinya kontrak baku atau perjanjian atau kontrak standar adalah kontrak yang klausula-klausula dibuat secara sepihak oleh pihak yang kedudukan dan posisi tawar lebih kuat dan dituangkan dalam suatu dokumen yang mengikat para pihak, sementara pihak lainnya yang mempunyai kedudukan dan posisi tawarnya lebih lemah tidak mempunyai peluang untuk merundingkan klausulaklausula tersebut melainkan hanya mempunyai dua pilihan menyetujui atau menolak. Adanya pilihan menyetujui atau menolak mengakibatkan kontrak baku dianggap tidak bertentangan dengan asas kebebasan berkontrak.

Secara teoritis, ada dua pendapat mengenai kedudukan perjanjian atau kontrak standar dalam hubungannya dengan asas kebebasan berkontrak. Sluijter berpendapat bahwa perjanjian standar (baku) bukan perjanjian, karena kedudukan pengusaha di dalam perjanjian adalah seperti pembentuk UU swasta (legio particuliere wetgever). Sementara itu Asser Rutten mengemukakan, setiap orang yang menandatangani perjanjian bertanggung jawab atas isi dan apa yang ditandatanganinya. Tanda tangan tersebut akan membangkitkan kepercayaan bahwa yang bertanda tangan mengetahui dan menghendaki isi formulir yang ditandatangani. 24 Berdasarkan pendapat tersebut, dapat dikemukakan bahwa perjanjian standar tidak bertentangan dengan asas kebebasan berkontrak jika penandatangan kontrak adalah atas dasar kesepakatan kedua belah pihak.

Pendapat lain dikemukakan oleh Mariam Darus Badrulzaman, yang menegaskan bahwa perjanjian standar bertentangan dengan asas kebebasan yang bertanggung jawab, terlebih lagi ditinjau dari asas-asas hukum nasional, di mana kepentingan masyarakatlah yang didahulukan. Dalam perjanjian standar kedudukan pelaku usaha dan konsumen tidak seimbang. Posisi yang didominasi 
pelaku usaha, membuka peluang untuk menyalahgunakan kedudukannya. Pelaku usaha hanya mengatur hak-haknya dan tidak kewajibannya. Perjanjian standar tidak boleh dibiarkan tumbuh secara liar dan karena itu perlu ditertibkan. ${ }^{25}$

Sebagai perangkat hukum dalam hubungan kontraktual, kontrak standar (baku) menurut Rayno Dwi Adityo, memiliki dimensi mata uang yang mempunyai dua sisi, sisi yang satu membolehkan bahkan mungkin sekali bahwa kontrak baku menjadi tidak sah dan sisi yang lainnya kontrak baku dapat dikatakan legal dan keberadaannya sangat dibutuhkan. ${ }^{26}$ Kontrak standar (baku) tetap perlu dipersoalkan apabila kontrak baku tersebut hanya mencantumkan hak-hak satu pihak saja tanpa mencantumkan kewajibannya. Kontrak standar (baku) menjadi tidak sah jika tidak memenuhi elemen-elemen yang dikehendaki Pasal 1320 jo Pasal 1338 KUH Perdata.

Dalam UU No. 8 Tahun 1999 tentang Perlindungan Konsumen (selanjutnya disebut UU Perlindungan Konsumen), pengaturan mengenai keabsahan kontrak baku terdapat dalam Pasal 18. Pasal 18 ayat (1) UU Perlindungan Konsumen memuat larangan bagi pelaku usaha memuat klausula baku dalam setiap dokumen atau perjanjian yang mengakibatkan antara lain: adanya pengalihan tanggung jawab, pelaku usaha berhak menolak penyerahan kembali barang yang diberi konsumen, pelaku usaha berhak menolak penyerahan kembali uang yang telah diserahkan konsumen, menyatakan pemberian kuasa dari konsumen kepada pelaku usaha, dan lain sebagainya. Kemudian Pasal 18 ayat (2) memuat larangan bagi pelaku usaha mencantumkan klausula baku yang letak atau bentuknya sulit terlihat atau tidak dapat dibaca secara jelas. Apabila pelaku usaha tetap memuat larangan sebagaimana yang ditetapkan dalam Pasal 18 ayat (1) dan (2) tersebut dalam dokumen atau perjanjian, maka berdasarkan Pasal 18 ayat (3) dinyatakan batal demi hukum. Ketentuan Pasal 18 ayat (3) UU Perlindungan Konsumen tersebut menunjukan bahwa kontrak baku yang memuat klausula baku yang dilarang tersebut bertentangan dengan asas kebebasan berkontrak.

Berbeda dengan keabsahan kontrak standar (baku) di negara Amerika Serikat yang menganut sistem common law yang menerapkan doktrin unconscionnability. Doktrin unconscionnability memberikan wewenang kepada hakim untuk mengesampingkan sebagian bahkan seluruh perjanjian demi menghindari hal-hal yang bertentangan dengan hati nurani. Dengan berlakunya doktrin tersebut, kontrak baku tetap saja bukan tidak absah tetapi perlu diteliti dengan keadilan dari perjanjian itu. ${ }^{27}$

Munir Fuady menjelaskan ada empat (4) prinsip yang harus diperhatikan dalam kontrak standar (baku) yaitu: 28

(a) Prinsip kesepakatan kehendak dari para pihak. Kesepakatan sebagai dasar sahnya perikat-

\footnotetext{
$25 \quad$ Ibid., 56.

26 Rayno Dwi Adityo, 'Efektifitas Kontrak Baku dalam Mobilitas Bisnis' (2016) 1 (1) Mahkamah 111 , 119.

27 M. Roesli, Sarbini, Bastianto Nugroho, 'Kedudukan Perjanjian Baku dalam Kaitannya Dengan Asas Kebebasan Berkontrak' (2019) 15 (1) Jurnal Ilmu Hukum 1, 5.

28 Munir Fuady, Hukum Kontrak (Dari Sudut Pandang Hukum Bisnis) (Buku ke-2, Citra Aditya Bakti 2003) 84-85.
} 
an tetap menjadi penentu sah atau tidaknya kontrak tersebut. Walaupun kontrak baku dibuat oleh salah satu pihak, unsur kesepakatan harus dapat dipenuhi. Kesepakatan itu dapat ditandai dengan ditandatanganinya kontrak atau dengan cara serah terima barang yang di transaksikan;

(b) prinsip asumsi resiko dari para pihak. Adanya asumsi risiko dalam perjanjian tidak dilarang. Artinya apabila salah satu pihak bersedia menanggung risiko tersebut, ketika risiko tersebut terjadi maka yang menyatakan bersedia tersebut harus menanggung risiko tersebut;

(c) prinsip kewajiban membaca (duty to read). Tanda tangan yang dibubuhkan dalam kontrak tersebut adalah tanda kalau mereka telah membaca sepenuhnya kontrak yang mereka sepakati;

(d) prinsip kontrak mengikuti kebiasaan. Kontrak sebagai role yang mengatur apa yang harus dilakukan dan tidak boleh dilakukan para pihak bukan berarti apa yang dicantumkan dalam kontrak boleh dilakukan atau tidak boleh dilakukan. Ada prinsip kebiasaan juga yang mengikat para pihak dalam perjanjian.

Konsekuensi yuridis dari adanya kewajiban membaca kontrak adalah para pihak tidak dapat mengelak untuk melaksanakan kontrak di kemudian hari dengan alasan bahwa ia sebenarnya tidak membaca klausula dalam kontrak, atau terjebak dengan klausula kontrak yang bersangkutan. Jadi pada asasnya yang berlaku adalah asas "kontrak adalah kontrak" (contract is contract) yang berlaku umum di mana-mana. Namun, nilai-nilai keadilan mengisyaratkan agar prinsip kewajiban membaca kontrak tersebut tidak pantas untuk diberlakukan secara mutlak. ${ }^{29}$

Pemanfaatan bentuk-bentuk kontrak baku dalam hubungan bisnis, pada dasarnya tidak dilarang. Hal ini dapat ditafsirkan dari ketentuan Pasal 1338 ayat (1) KUH Perdata dari kata semua, yaitu ada kebebasan bagi setiap subjek hukum untuk menentukan bentuk perjanjian. Melalui asas kebebasan berkontrak, subjek hukum mempunyai kebebasan untuk membuat perjanjian, termasuk untuk membuka peluang pada subjek hukum untuk membuat perjanjian baru yang belum diatur dalam $\mathrm{KUH}$ Perdata agar dapat mengikuti kebutuhan masyarakat akibat perkembangan zaman (perjanjian Innominat). ${ }^{30}$

Ada tiga (3) tolak ukur yang dapat dipergunakan untuk menentukan apakah klausul atau syarat-syarat dan ketentuan-ketentuan dalam kontrak baku dapat berlaku dan mengikat para pihak. Tolak ukur itu adalah UU, moral, dan ketertiban umum. Tolak ukur lainnya adalah adanya kepatutan, kebiasaan, dan UU. Jika dapat digabungkan tolak ukur tersebut adalah UU, moral, ketertiban umum, kepatutan dan kebiasaan. Jadi tidak ada kebebasan yang mutlak. Pemerintah dapat mengatur atau melarang suatu kontrak yang dapat berakibat buruk atau merugikan kepentingan masyarakat. ${ }^{31}$

29 Muhammad Syaifuddin, Hukum Kontrak Memahami Kontrak dalam Perspektif Filsafat, Teori, Dogmatik, dan Praktik Hukum (Seri Pengayaan Hukum Perikatan, Mandar Maju 2012) 223.

30 Christiana Tri Budhayati, 'Asas Kebebasan Berkontrak dalam Hukum Perjanjian di Indonesia' (2009) 10 (3) Jurnal Widya Sari 232, 233.

31 Irdanuraprida Idris, 'Ketidakadilan dalam Kebebasan Berkontrak dan Kewenangan Negara Untuk Membatasinya' (2007) 4 (2) Lex Jurnalica 77, 86. 


\section{Bentuk Kebebasan Berkontrak Dalam Kontrak Standar Pengadaan Barang dan Jasa Pemerintah}

Pengadaan barang dan jasa pemerintah melibatkan dua pihak, yaitu pemerintah sebagai pihak pengguna barang dan jasa dan pelaku usaha sebagai pihak penyedia barang dan jasa. Para pihak tidak mempunyai posisi tawar yang seimbang. Pihak yang mempunyai posisi tawar yang lebih kuat adalah pemerintah, sehingga pemerintah yang menentukan klausula-klausula yang terdapat dalam syarat-syarat umum kontrak, syarat-syarat khusus kontrak, yang kemudian menjadi dokumen satu kesatuan yang tidak terpisahkan dengan surat perjanjian (kontrak). Pihak penyedia barang dan jasa hanya berkedudukan sebagai pihak yang menyetujui atau tidak menyetujui atas kontrak yang telah dibuat oleh pemerintah.

Kontrak pengadaan barang dan jasa pemerintah termasuk dalam pengertian perjanjian atau kontrak standar. Artinya syarat-syarat umum, syarat-syarat khusus, dan surat perjanjian (kontrak) yang merupakan satu kesatuan dokumen sudah dipersiapkan oleh pemerintah sebagai pengguna barang dan jasa. Tahapan kontrak pengadaan barang dan jasa terdiri atas tiga tahap yaitu:1) tahap pra kontraktual atau sebelum kontrak ditandatangani; 2) tahap kontraktual atau tahap setelah kontrak ditandatangani; dan 3) tahap post kontraktual atau setelah kontrak dilaksanakan. Implementasi bentukbentuk kebebasan berkontrak dalam penyelenggaraan pengadaan barang dan jasa pemerintah yang diatur dalam Perpres Pengadaan Barang/ Jasa Pemerintah, adalah sebagai berikut:

\section{Tahapan pra kontraktual}

Tahapan ini dimulai pada saat pelaksanaan pemilihan penyedia barang dan jasa, baik melalui tender/seleksi maupun melalui tender cepat. Pelaksanaan tender dilakukan setelah Rencana Umum Pengadaan (RUP) diumumkan. Pengumuman RUP merupakan pemberitahuan atau undangan secara terbuka kepada yang memenuhi syarat untuk berpartisipasi dalam pengadaan barang dan jasa. Pengumuman hanya dimaksudkan sebagai ajakan kepada pihak lain baik kalangan luas maupun terbatas, untuk mengikuti tender dan memasukan penawarannya (submit a tender). Oleh sebab itu menurut Y. Sogar Simamora, yang terkandung dalam pengumuman itu hanya dinilai sebagai proklamasi. ${ }^{32}$

Kegiatan pendaftaran dan pengambilan dokumen pemilihan merupakan tahap awal dalam proses pembentukan kontrak. Dengan melakukan pendaftaran dan pengambilan dokumen pemilihan, menunjukan pihak penyedia barang dan jasa berkeinginan untuk membuat kontrak dengan pihak pengguna barang dan jasa. Dari pihak pengguna barang dan jasa dengan menerima pendaftaran dan memberikan dokumen pemilihan kepada pihak penyedia barang dan jasa menunjukan pula adanya keinginan untuk membuat kontrak dengan pihak penyedia. Bentuk penerapan kebebasan berkontrak dalam kegiatan pendaftaran dan

32 Yohanes Sogar Simamora, Hukum Kontrak Pengadaan Barang dan Jasa Pemerintah di Indonesia (n 2) 171. 
pengambilan dokumen pemilihan, adalah kebebasan untuk membuat kontrak atau tidak membuat kontrak.

Proses selanjutnya setelah pendaftaran dan pengambilan dokumen pemilihan adalah pemberian penjelasan. Pada saat pemberian penjelasan, pihak penyedia barang dan jasa diberi hak dan kesempatan melakukan negosiasi dengan pengguna barang dan jasa untuk melakukan perubahan terhadap dokumen pemilihan. Proses negosiasi merupakan sarana para pihak untuk berkomunikasi yang pada prinsipnya bertujuan untuk mencapai kesepakatan. Adanya perubahan terhadap dokumen pemilihan sekalipun hanya menyangkut aspek teknis dari pengadaan barang dan jasa misalnya besaran volume pekerjaan dan jangka waktu pelaksanaan pekerjaan yang ditawarkan oleh pengguna, menunjukan adanya kesepakatan para pihak, sehingga proses negosiasi dalam pemberian penjelasan tersebut dapat dikatakan merupakan penerapan kebebasan berkontrak dalam bentuk kebebasan untuk menentukan isi dan syarat-syarat kontrak.

Dengan selesainya pemberian penjelasan, penyedia barang dan jasa memasukan penawaran. Penawaran pada dasarnya adalah usulan atau ajakan untuk mengadakan perjanjian. Namun demikian tidak setiap usulan dapat dinilai sebagai penawaran. Dalam penawaran harus diungkap secara jelas pokok yang diperjanjikan. ${ }^{33}$ Hal yang pokok dari perjanjian lazim disebut unsur essentialia. ${ }^{34}$ Unsur essentialia adalah unsur perjanjian yang selalu harus ada di dalam suatu perjanjian, tanpa adanya unsur tersebut perjanjian tidak mungkin ada. Misal dalam perjanjian jual beli, harga dan barang yang disepakati kedua belah pihak harus ada. 35

Berdasarkan ketentuan tersebut di atas, dalam dokumen penawaran, unsur yang harus ada adalah paket pekerjaan yang akan dilaksanakan, lokasi pekerjaan, dan perkiraan nilai pekerjaan. Semua yang tercantum dalam dokumen penawaran secara hukum mengikat. Artinya, bila pihak lain melakukan akseptasi maka isi penawaran itu berlaku baik mengenai unsur pokok yang secara tegas dikemukakan, maupun unsur tambahan bila tentang hal ini juga dikemukakan. ${ }^{36}$

Kebebasan berkontrak pada saat pemasukan penawaran termasuk bentuk penerapan kebebasan untuk mengadakan kontrak atau perjanjian dengan siapa yang dikehendaki. Kebebasan berkontrak pada saat pemasukan penawaran dapat disimpulkan dari ketentuan bahwa penyedia barang dan jasa yang berhak memasukan penawaran adalah penyedia barang dan jasa yang memperoleh dokumen pengadaan yang substansinya sudah dinegosiasikan dan disepakati dan tertuang dalam Berita Acara Pemberian Penjelasan (BAPP) pada tahapan pemberian penjelasan.

Selanjutnya adalah pembukaan dokumen penawaran diikuti dengan evaluasi penawaran. Kebebasan dalam tahap evaluasi penawaran adalah kebebasan pengguna barang dan jasa untuk menilai dan menentukan syarat

Ibid,. 168-169.

Subekti, Aneka Perjanjian (cet. ke-6, Alumni 1995) 2.

J. Satrio, Hukum Perjanjian (Citra Aditya Bakti 1992) 67.

Yohanes Sogar Simamora, Hukum Kontrak Pengadaan Barang dan Jasa Pemerintah di Indonesia (n 2) 171. 
dalam dokumen penawaran yang tidak bertentangan dengan peraturan perundang-undangan yang berlaku. Penetapan pemenang dilakukan setelah pengumuman hasil evaluasi penawaran. Penetapan pemenang tersebut dapat dimaknai sebagai kebebasan untuk memilih dengan pihak mana kontrak akan dibuat.

Tahapan selanjutnya dalam proses pelaksanaan pengadaan barang dan jasa adalah melakukan sanggahan dan penunjukan penyedia barang dan jasa. Sanggahan yang dilakukan terhadap penetapan pemenang pada dasarnya merupakan hak penyedia barang dan jasa untuk mengkritisi hasil penetapan pemenang yang dianggap tidak memenuhi persyaratan dalam proses pelaksanaan pengadaan barang dan jasa. Penunjukan penyedia barang dan jasa menunjukan kebebasan dalam menentukan dengan pihak mana kontrak akan dibuat dengan memperhatikan dan menilai dokumen penawaran yang diajukan penyedia barang dan jasa.

Mencermati proses pelaksanaan pemilihan dalam penyelenggaraan pengadaan barang dan jasa, dapat dikemukakan bahwa pada tahap pra kontraktual atau sebelum pembentukan kontrak terjadi proses penawaran (offer) dan penerimaan (acceptance). Dalam proses tersebut terjadi negosiasi untuk mencapai kesepakatan diantara kedua pihak namun belum terdapat suatu hubungan hukum. Hubungan hukum diantara para pihak baru muncul setelah para pihak mengadakan kesepakatan dalam sebuah kontrak atau perjanjian.

Konsep penawaran (offer) dan penerimaan (acceptance) berasal dari common law system. Dalam common law system, penawaran dan penerimaan merupakan hal yang sangat penting dalam pembentukan suatu perjanjian, karena dalam proses ini dapat diketahui keinginan dari salah satu pihak yang dimanifestasikan dalam bentuk penawaran kepada pihak lainnya yang akan dinyatakan dalam suatu penerimaan. Ketika suatu penawaran diajukan oleh salah satu pihak dan diterima oleh pihak lainnya, maka pada saat itulah terjadi persesuaian kehendak (meeting of minds) dari dua pihak atau lebih.

Dalam KUH Perdata tidak ada pengaturan mengenai penawaran dan penerimaan. Penawaran dan penerimaan dikenal sebagai persesuaian kehendak diantara para pihak sebagaimana diatur dalam Pasal 1320 angka (1) KUH Perdata yaitu kesepakatan mereka yang mengikatkan dirinya. Pengertian kesepakatan dimaksudkan bahwa para pihak yang mengadakan perjanjian harus bersepakat dan setuju mengenai hal-hal yang diperjanjikan. Kata sepakat mencakup pengertian tidak saja untuk mengikatkan diri, tetapi berhak atas prestasi yang telah diperjanjikan. Tanpa sepakat dari salah satu pihak yang membuat perjanjian, maka perjanjian yang dibuat dapat dibatalkan. Orang tidak dapat dipaksa untuk memberikan sepakatnya. Sepakat yang diberikan dengan paksa adalah contradiction interminis. 37

Kesepakatan adalah persesuaian pernyataan kehendak antara satu orang atau lebih dengan pihak lainnya, yang harus sesuai adalah pernyataannya, karena kehendak para pihak tidak dapat diketahui orang lain.

37 Ghansam Anand, 'Prinsip Kebebasan Berkontrak dalam Penyusunan Kontrak' (2011) 26 (2) Yuridika 89, 92. 
Persesuaian kehendak tersebut harus diberikan secara bebas, artinya kesepakatan para pihak tidak mengandung cacat kehendak sebagaimana dimaksud dalam Pasal 1321 KUH Perdata yaitu, tiada sepakat yang sah apabila sepakat itu diberikan karena kekhilafan, atau diperolehnya dengan paksaan dan penipuan. Kesepakatan adalah memberikan informasi bahwa suatu perjanjian pada dasarnya sudah ada sejak tercapainya kata sepakat diantara para pihak dalam perjanjian tersebut. 38 Kata sepakat mencakup pengertian tidak saja untuk mengikatkan diri, tetapi berhak atas prestasi yang telah diperjanjikan. Dalam suatu kontrak masing-masing pihak tidak saja mempunyai kewajiban, tetapi berhak juga atas prestasi yang telah diperjanjikan.

Pada dasarnya dalam proses pengadaan barang dan jasa pemerintah, dilakukan berdasarkan kehendak bebas para pihak. Akan tetapi mengingat pihak penyedia barang dan jasa mempunyai ketergantungan secara ekonomis dengan pihak pemerintah sebagai pengguna barang dan jasa, maka ada kecenderungan terjadi penyalahgunaan keadaan yang dilakukan oleh pemerintah yang tidak dapat dihindari oleh penyedia barang dan jasa, sehingga dapat saja terjadi pernyataan persesuaian kehendak atau kesepakatan dari pihak penyedia jasa tidak sesuai dengan kehendaknya.

Dalam kaitannya dengan persesuaian antara kehendak dan pernyataan yang terjadi antara pemerintah sebagai pengguna barang dan jasa dengan penyedia barang dan jasa, maka teori yang dapat digunakan adalah teori kepercayaan. Hal ini karena teori kepercayaan menyatakan bahwa pernyataan yang menimbulkan kepercayaan saja yang menimbulkan perjanjian. Suatu kata sepakat dianggap terjadi manakala ada pernyataan yang secara objektif dapat dipercaya. Pernyataan yang secara objektif dapat dipercaya dari penyedia jasa dapat dilihat dalam dokumen penawaran yang diajukan oleh penyedia barang dan jasa dan dalam BAPP pada saat pemberian penjelasan. Sedangkan dari pihak pemerintah, pernyataan objektif yang dapat di percaya adalah ketika melakukan akseptasi terhadap penawaran yang dilakukan oleh penyedia barang dan jasa. Wujud dari akseptasi tersebut adalah dengan ditetapkannya penyedia sebagai pemenang dalam proses pengadaan barang dan jasa.

Berdasarkan uraian di atas sekalipun ada kecenderungan pihak pemerintah sebagai pengguna barang dan jasa melakukan penyalahgunaan keadaan dalam proses persesuaian kehendak, namun dapat ditegaskan bahwa persesuaian kehendak atau kesepakatan para pihak pada tahapan pra kontraktual mencerminkan adanya kebebasan berkontrak.

Kebebasan berkontrak pada tahap pra kontraktual tentunya harus sesuai juga dengan asas itikad baik. Kewajiban hukum atas itikad baik dalam tahap pra kontraktual membawa konsekuensi hukum terhadap kekuatan mengikat janji-janji pra kotraktual. Peraturan perundangundangan di Indonesia tidak mengatur secara khusus mengenai janji-janji pra kontraktual. Setiap jenis pengadaan barang dan jasa harus mengacu pada Perpres Pengadaan Barang/Jasa

38 Ery Agus Priyono, 'Aspek Keadilan dalam Kontrak Bisnis di Indonesia [Kajian Pada Perjanjian Waralaba]' (2018) 4 (1) Jurnal Law Reform 15, 22. 
Pemerintah, baik menyangkut metode pemilihan penyedia barang dan jasa, yaitu tender/seleksi, tender cepat, $e^{-}$ purchasing, penunjukan langsung, dan pengadaan langsung, maupun dalam proses pembentukan kontraknya.

\section{Tahap Kontraktual}

Penandatanganan kontrak sampai pelaksanaan kontrak selesai merupakan tahap kontraktual. Penandatanganan kontrak menunjukkan adanya kesepakatan bahwa para pihak setuju dengan isi kontrak. Penandatanganan suatu perjanjian atau kontrak mengandung arti bahwa para pihak sudah setuju dengan perjanjian atau kontrak tersebut, termasuk sudah setuju dengan isinya, karena sebelum menandatangani suatu perjanjian atau kontrak, para pihak mempunyai kewajiban membaca (duty to read) terhadap suatu perjanjian atau kontrak. ${ }^{39}$

Perubahan terhadap kontrak pengadaan barang dan saja dapat terjadi apabila terdapat perbedaan yang signifikan antara kondisi lokasi pekerjaan pada saat pelaksanaan dengan gambar dan spesifikasi yang ditentukan dalam kontrak. Selain itu perubahan kontrak dapat juga dilakukan apabila ada perpanjangan waktu pelaksanaan pekerjaan, dikarenakan adanya pekerjaan tambahan, perubahan desain, keterlambatan yang disebabkan oleh Pejabat Pembuat Komitmen (PPK), masalah lain yang timbul di luar kendali penyedia, dan keadaan kahar. Berkaitan dengan ketentuan yang memperbolehkan perubahan kontrak pada saat pelaksanaan kontrak sebagaimana diuraikan di atas, dapat disimpulkan bahwa para pihak pada saat pelaksanaan kontrak mempunyai kebebasan untuk menentukan syaratsyarat yang diperjanjikan antara lain melakukan perubahan dari aspek teknis dan harga yang kemudian dituangkan dalam adendum kontrak. Namun apabila dicermati bentuk kebebasan berkontrak pada tahap ini, pada dasarnya hanya melaksanakan ketentuan yang termuat dalam perjanjian dan UU.

Dalam tahap kontraktual ini, kontrak pengadaan barang dan jasa yang sudah ditandatangani, mempunyai daya mengikat sebagaimana layaknya UU. Kekuatan mengikat kontrak harus diiringi dengan itikad baik sebagaimana Pasal 1338 KUH Perdata ayat (3) yang menyebutkan, bahwa kontrak harus dilaksanakan dengan itikad baik. Itikad baik di sini adalah itikad baik pada waktu pelaksanaan hak-hak dan kewajiban yang tercantum dalam kontrak atau itikad baik dalam arti objektif. Dalam pelaksanaan itikad baik ini, hakim berkuasa untuk menyimpang dari isi kontrak jika pelaksanaan kontrak bertentangan dengan itikad baik.

Ketentuan mengenai itikad baik tidak ada pengaturannya dalam Perpres Pengadaan Barang/Jasa Pemerintah, tetapi ketentuan mengenai sanksi terhadap perbuatan penyedia barang/jasa yang termuat pada Pasal 78 dapat digolongkan sebagai kewajiban itikad baik pada tahap pra kontraktual dan tahap kontraktual. Kewajiban itikad baik pada tahap kontraktual adalah

39 Munir Fuady, Hukum Kontrak (Dari Sudut pandang Hukum Bisnis) (PT. Citra Aditya Bakti 1999) 89. 
kewajiban para pihak untuk melaksanakan kontrak atas dasar saling percaya dan kesepakatan untuk melaksanakan kontrak dengan jujur, dan apabila ada yang dirugikan dapat diselesaikan dengan tindakan terbaik sehingga tujuan kontrak dapat terpenuhi.

\section{Tahap Post Kontraktual}

Tahapan post kontraktual dalam penyelenggaraan pengadaan barang dan jasa dimulai setelah serah terima hasil pekerjaan yaitu setelah pekerjaan selesai $100 \%$ (seratus persen) sesuai dengan ketentuan dalam kontrak, penyedia mengajukan permintaan secara tertulis kepada PPK untuk serah terima barang dan jasa (Pasal 57 ayat (1) Perpres Pengadaan Barang/Jasa Pemerintah. Untuk pekerjaan jasa konstruksi, tanggung jawab penyedia jasa berlaku sesuai dengan umur konstruksi yang direncanakan dengan maksimal 10 (sepuluh) tahun sejak penyerahan akhir pekerjaan konstruksi.

Apabila terjadi kegagalan bangunan yang disebabkan oleh kesalahan perencana konstruksi, maka perencana konstruksi hanya bertanggung jawab atas ganti rugi sebatas hasil perencanaannya yang belum/tidak diubah. Apabila terjadi kegagalan bangunan yang disebabkan oleh kesalahan pelaksana konstruksi dan pengawas konstruksi, maka tanggung jawab berupa sanksi dan ganti rugi dapat dikenakan pada usaha orang perseorangan dan atau badan usaha pelaksana dan pengawas konstruksi penandatangan kontrak kerja konstruksi. Pengguna jasa konstruksi juga bertanggung jawab atas kegagalan bangunan yang disebabkan oleh kesalahan pengguna jasa.
Penilaian terhadap kegagalan bangunan tersebut berdasarkan Pasal 36 Peraturan Pemerintah Nomor 29 Tahun 2000 tentang Penyelenggaraan Jasa Konstruksi, sebagaimana telah diubah dengan Peraturan Pemerintah Nomor 59 Tahun 2010 dan Peraturan Pemerintah Nomor 79 Tahun 2015 tentang Perubahan Kedua Peraturan Pemerintah Nomor 29 Tahun 2000 dan Peraturan Pemerintah Nomor 54 Tahun 2016 tentang Perubahan Ketiga tentang Penyelenggaraan Jasa Konstruksi (selanjutnya disingkat PP Penyelenggaraan Jasa Konstruksi), dilakukan oleh satu atau lebih penilai ahli yang dipilih dan disepakati bersama oleh penyedia jasa dan pengguna jasa, dan pemerintah berwenang memberikan pendapat dalam penunjukan, proses penilaian dan hasil kerja penilai ahli yang dibentuk dan disepakati oleh para pihak.

Berdasarkan uraian di atas, dapat ditegaskan bahwa pada tahap post kontraktual, prinsip kebebasan berkontrak tercermin dari ketentuan yang mengatur mengenai pemilihan penilai ahli yang disepakati bersama antara pengguna jasa dengan penyedia jasa. Bentuk kebebasan berkontrak pada tahap post kontraktual ini termasuk dalam kriteria kebebasan untuk menentukan ketentuan-ketentuan hukum yang berlaku apabila terjadi kegagalan bangunan.

Apabila dicermati, dalam tahapan post kontraktual juga terkandung asas kekuatan mengikat. Ketentuanketentuan yang mengatur kewajiban dan tanggung jawab atas kegagalan bangunan serta ganti rugi yang harus dibayarkan, pada dasarnya merupakan ketentuan mengenai pelaksanaan atau pemenuhan kewajiban yang telah disepakati dalam kontrak, sebagai 
contoh ganti rugi dalam hal terjadi kegagalan bangunan dilakukan dengan mekanisme pertanggungan pihak ketiga atau asuransi, sesuai dengan ketentuan yang diatur dalam Pasal 46 PP Penyelenggaraan Jasa Konstruksi, yaitu: (a) Persyaratan dan jangka waktu serta nilai pertanggungan ditetapkan atas dasar kesepakatan; (b) premi dibayar oleh masing-masing pihak dan biaya premi yang menjadi tanggungan penyedia jasa menjadi bagian dari unsur biaya pekerjaan konstruksi. Dalam hal pengguna jasa tidak bersedia memasukan biaya premi sebagaimana dimaksud, maka resiko kegagalan bangunan menjadi tanggung jawab pengguna jasa.

Dengan demikian pemenuhan kewajiban yang telah disepakati merupakan implementasi dari asas kekuatan mengikat kontrak yang diatur dalam Pasal 1338 KUH Perdata. Selain itu dalam tahap post kontraktual juga terkandung asas itikad baik yang diatur dalam Pasal 1338 ayat (3) KUH Perdata, yaitu itikad baik dalam arti objektif yaitu adanya kepatutan dalam melaksanakan kewajiban dan tanggung jawab serta memberikan ganti rugi dalam hal terjadinya kegagalan bangunan.

Berdasarkan uraian di atas, dapat ditegaskan bahwa pada tahap post kontraktual, bentuk penerapan prinsip kebebasan berkontrak tercermin dari ketentuan yang mengatur mengenai pemilihan penilai ahli yang disepakati bersama antara pengguna jasa dengan penyedia jasa. Bentuk penerapan kebebasan berkontrak pada tahap post kontraktual yaitu dalam bentuk kebebasan untuk menentukan ketentuan-ketentuan hukum yang berlaku apabila terjadi kegagalan bangunan, yang sebenar- nya juga merupakan pelaksanaan dari ketentuan perjanjian dan UU.

\section{PENUTUP}

Kebebasan berkontrak adalah menyerahkan isi setiap kontrak dan ukuran penilaian yang disyaratkan diperbolehkannya pelaksanaan kontrak kepada kehendak bebas para pihak dalam kontrak. Perjanjian atau kontrak standar pada prinsipnya bertentangan dengan asas kebebasan berkontrak, akan tetapi perjanjian standar yang memenuhi elemenelemen yang dikehendaki Pasal 1320 jo Pasal 1338 KUH Perdata tetap dianggap sah.

Bentuk penerapan prinsip kebebasan berkontrak dalam kontrak pengadaan barang dan jasa pada tahap pra kontraktual adalah dalam bentuk kebebasan untuk membuat kontrak dengan siapa yang dikehendaki dan kebebasan untuk menentukan isi dan syarat kontrak. Pada tahapan kontraktual penerapan kebebasan berkontrak adalah dalam bentuk kebebasan untuk membuat atau tidak membuat kontrak dengan menandatangani atau tidak menandatangani kontrak, dan kebebasan untuk menentukan isi dan syaratsyarat kontrak jika terjadi perubahan kontrak pada saat pelaksanaan kontrak. Namun apabila dicermati penerapan kebebasan berkontrak pada tahap ini, pada dasarnya hanya melaksanakan ketentuan yang termuat dalam kontrak dan UU. Pada tahapan post kontraktual yaitu dalam hal ini untuk pelaksanaan pekerjaan jasa konstruksi, ruang lingkup penerapan kebebasan berkontrak adalah pada saat terjadinya kegagalan bangunan, yaitu kebebasan berkontrak tercermin dari adanya kesepakatan 
para pihak untuk menetapkan penilai ahli yang menilai terjadi kegagalan bangunan, yang sebenarnya juga merupakan pelaksanaan dari ketentuan kontrak dan UU.

Untuk itu pada tahap pra kontraktual, perlu ditambah ketentuan mengenai sanksi gugatan secara perdata terhadap pelanggaran kesepakatan pada saat pembentukan kontrak. Secara prosedural, kontrak pengadaan barang dan jasa belum memenuhi keadilan berkontrak. Untuk memenuhi kontrak yang berkeadilan, pemerintah perlu melakukan perubahan terhadap ketentuan mengenai hak dan kewajiban para pihak dalam proses pembentukan kontrak.

\section{DAFTAR BACAAN}

\section{Buku}

Badrulzaman MD, Aneka Hukum Bisnis (Alumni 1994).

MD, Kompilasi Hukum Perikatan (Citra Aditya Bakti 2001).

Fuady M, Hukum Kontrak (Dari Sudut Pandang Hukum Bisnis) (PT. Citra Aditya Bakti 1999).

Hukum Kontrak (Dari Sudut Pandang Hukum Bisnis) (Buku ke-2, Citra Aditya Bakti 2003).

Hernoko AY, Hukum Perjanjian, Asas Proporsionalitas dalam Kontrak Komersial (Kencana Prenada Media Grup 2001).

Khairandy R, Itikad Baik dalam Kebebasan Berkontrak (Program Pascasarjana Fakultas Hukum Universitas Indonesia 2003).

Indonesia dalam
Perbandingan (FH UII Prespektif
2013).

Mahadi, Falsafah Hukum Suatu Pengantar (Citra Aditya Bakti 1989).

Paton GW, A Textbook of Jurisprudence (3rd edn, ELBS And Oxford University Press 1971).

Rahardjo S, Ilmu Hukum (cet. ke-2, Citra Aditya Bakti 2000).

Satrio J, Hukum Perjanjian (Citra Aditya Bakti 1992).

Simamora YS, Hukum Kontrak Pengadaan Barang dan Jasa Pemerintah di Indonesia (ed. ke-2, Kantor Hukum WINS \& Partners 2005).

Sofwan SSM, Hukum Perdata: Hukum Perutangan (Seksi Hukum Perdata Fakultas Hukum Universitas Gadjah Mada 1980).

Subekti, Aneka Perjanjian (cet. ke-6, Alumni 1995).

Syahdeini SR, Kebebasan Berkontrak dan Perlindungan yang Seimbang Bagi Para Pihak dalam Perjanjian Kredit Bank di Indonesia (Institut Bankir Indonesia 1993).

Syaifuddin M, Hukum Kontrak Memahami Kontrak dalam Perspektif Filsafat, Teori, Dogmatik, dan Praktik Hukum (Seri Pengayaan Hukum Perikatan, Mandar Maju 2012).

\section{Artikel Jurnal}

Adityo RD, 'Efektifitas Kontrak Baku dalam Mobilitas Bisnis' (2016) 1 (1) Mahkamah.

Anand G, 'Prinsip Kebebasan Berkontrak dalam Penyusunan Kontrak' (2011) 26 (2) Yuridika.

Arifin M, 'Penyalahgunaan Keadaan Sebagai Faktor Pembatas Kebebasan Berkontrak' (2011) 22 (2) Jurnal Ilmu Hukum.

Aryawan MR, 'Asas Kebebasan Berkontrak dalam Kaitannya dengan Kewenangan Hakim untuk Menilai Eksistensi Kontrak' (2003) 1 (1) Jurnal Ilmu Hukum. 
Budhayati CT, 'Asas Kebebasan Berkontrak dalam Hukum Perjanjian di Indonesia' (2009) 10 (3) Jurnal Widya Sari.

Gunawan J, 'Reorientasi Hukum Kontrak di Indonesia' (2003) 22 (6) Jurnal Hukum Bisnis.

Idris I, 'Ketidakadilan dalam Kebebasan Berkontrak dan Kewenangan Negara Untuk Membatasinya' (2007) 4 (2) Lex Jurnalica.

Khoiriyah N dan Santoso L, 'Batasan Kebebasan Berkontrak dalam Kontrak Konvensional dan Kontrak Syariah' (2017) 5 (1) AHKAM.

Listiyanto A, 'Pembaharuan Regulasi Pengadaan Barang dan Jasa Pemerintah' (2012) 1 (1) RechtsVinding: Media Pembinaan Hukum Nasional.

Priyono EA, 'Aspek Keadilan dalam Kontrak Bisnis di Indonesia [Kajian Pada Perjanjian Waralaba]' (2018) 4 (1) Jurnal Law Reform.

Roesli M, Sarbini, Bastianto Nugroho, 'Kedudukan Perjanjian Baku dalam Kaitannya Dengan Asas Kebebasan Berkontrak' (2019) 15 (1) Jurnal Ilmu Hukum.

Rusli T, 'Asas Kebebasan Berkontrak Sebagai Dasar Perkembangan Perjanjian di Indonesia' (2015) 10 (1) Pranata Hukum Jurnal Ilmu Hukum.

Simanjuntak R, 'Akibat dan TindakanTindakan Hukum Terhadap Pencantuman Klausula Baku dalam Polis Asuransi yang Bertentangan Dengan Pasal 18 Undang-Undang Nomor 8 Tahun 1999 Tentang Perlindungan Konsumen' (2003) 22 (2) Jurnal Hukum Bisnis.

Sjaiful M, 'Karakteristik Asas Kebebasan Berkontrak dalam Perjanjian Berbasis Syariah' (2015) 15 (1) Jurnal Universitas Halu Oleo.

\section{Kamus}

Kamus Besar Bahasa Indonesia Kamus versi online/daring (dalam jaringan), <https://kbbi. web.id/asas > diakses 20 Maret 2020.

\section{Peraturan Perundang-Undangan}

Kitab Undang-Undang Hukum Perdata.

Undang-Undang Nomor 2 Tahun 2017 tentang Jasa Konstruksi.

Peraturan Presiden Nomor 16 Tahun 2018 tentang Pengadaan Barang/Jasa Pemerintah.

Peraturan Pemerintah Nomor 29 Tahun 2000 sebagaimana telah diubah dengan Peraturan Pemerintah Nomor 59 Tahun 2010 dan Peraturan Pemerintah Nomor 79 Tahun 2015 tentang Perubahan Kedua Peraturan Pemerintah Nomor 29 Tahun 2000 dan Peraturan Pemerintah Nomor 54 Tahun 2016 tentang Perubahan Ketiga tentang Penyelenggaraan Jasa Konstruksi.

Peraturan Kepala Lembaga Kebijakan Pengadaan Barang/Jasa Pemerintah Nomor 15 Tahun 2012 tentang Standar Dokumen Pengadaan Barang/Jasa Pemerintah.

Peraturan Kepala Lembaga Kebijakan Pengadaan Barang/Jasa Pemerintah Nomor 1 Tahun 2015 tentang E-Tendering. 
